\title{
Costs and benefits to Red-breasted Mergansers nesting in tern and gull colonies.
}

\author{
Andrew D. Young \\ Department of Renewable Resources \\ McGill University, Montroal
}

Apr 11, 1985

A thesis submitted to the Faculty of Graduate Studies and Research in pertial fulfillment of the requirements for the degree of Master of Science.

(C) Andrew D. Young, 1985 


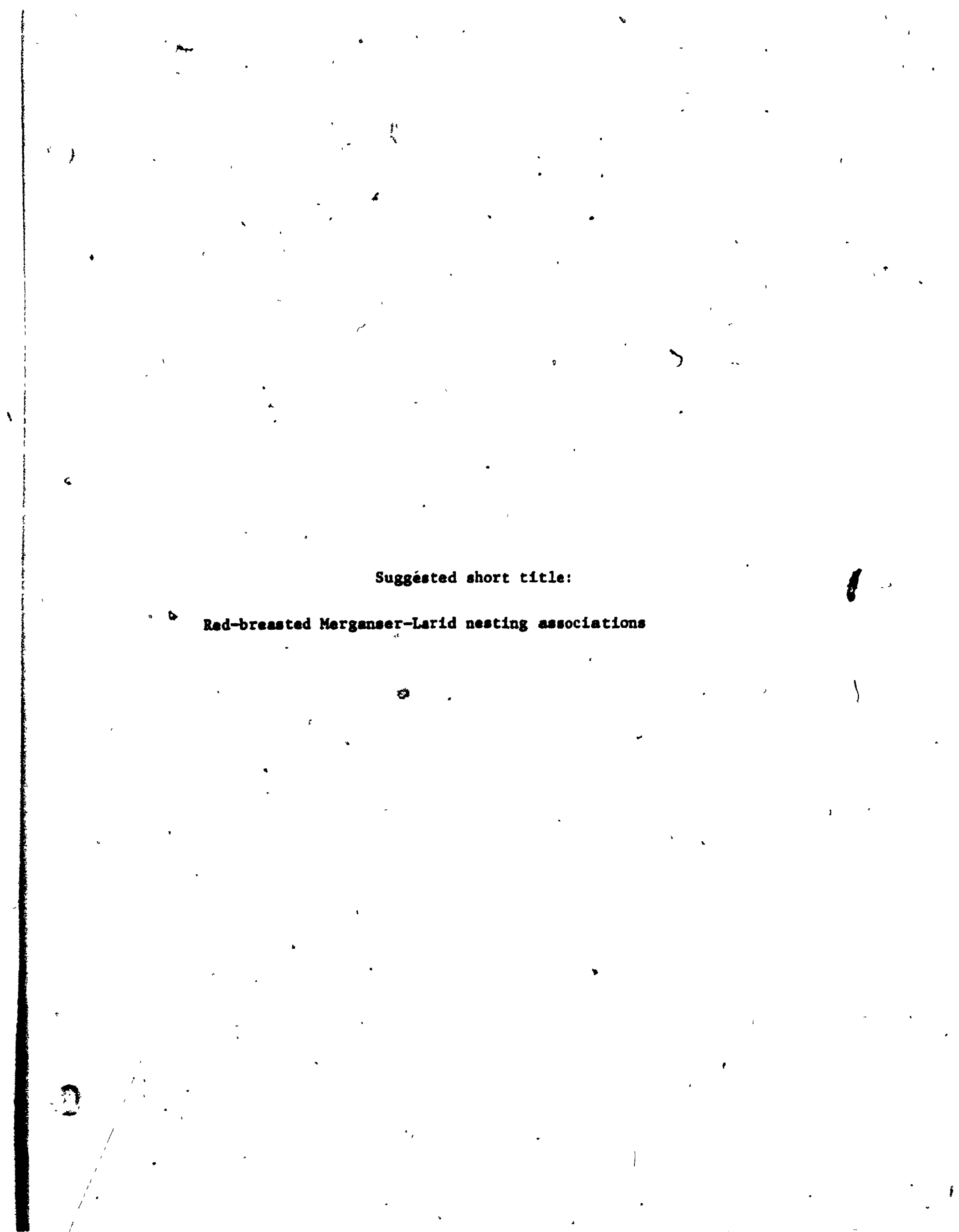


ABSFRACT

The costs and benefits to Red-breasted Mergensers (Merqus serrator) - nesting in a Common Tern (Sterne hirundo) colony and a Herring (Larus argentatus) and Greater Black-backed Gull (L. marinus) colony were studied from 5 June to 17 August 1984 on 1oplands off the east coast of New Brunswick. Merganser neste outside larid colonies were preyed upon oignificenty more than nests in the tern colony while no difference dxisti with nests in the gull colony. Nests in the tern colony were more likely to be abandoned probably due to inter- and intra-specific interaction including neat parasitiam. Clumped ' neste in the tern colqny were not initieted in greater synchrony then dispersed nests. The morganser-gull nesting association cennot be accounted for solely by an enti-predator hypothosie. It is postulated that the protective benefit for merganeer neste in tern colonios accounts for the ovolution and mintenence of the neating asciociation. 


\section{$d$}

RESUME

Les co0ts et bénéfices encourus par des Bec-Scies à Poitrine Rousse (Merque serrator) nichant dans une colonie de Sternes Communes (Sterna hirundo) et dans une colonie de Goélends Argentés (Larus argentatus) et de Goblande Manteau Noir (L. marinua) furent Gtudiés du 5 juin au 17 aodt 1984, sur des 1 les au large de la cote est du Nouveau-Brunswick. Les nids de Bec-Scies situés à l'extérieur des colonies de laridés ont subi une predation aignificativement plus forte que les nids situés dans la colonie de sternes, alors qu'aucune différence ne fut observée pour les nide sityóro dans la colonie de goé lands. Les nide aitués à l'intóriour de la colonio de sternes avaient une plus grande probabilité d'etro abandonnés, probablement a cause d'interactions inter- et intraepocifiques, incluant le parasitisme des nids. La synchronisation des nide groupés l'intérieur de la colonie de sternes n'est pas supérieure cello des nide diepersés. L'aseociation Bec-Scies-Goblandé no pout Btre completement expliqude par une hypothise d'anti-predation. Il est postulo que la protection dont bónoficient les nids de Bec-5cies a l'intórieur des colonies de eternes explique l'óvolution et le maintien de l'esecciation en période de nidification. 
i : TABLE of CONTENTS

- Page

Preface $\ldots \ldots \ldots \ldots \ldots \ldots \ldots \ldots \ldots \ldots \ldots \ldots \ldots \ldots$ I

Literature Reviow ................... 3

Introduction $\ldots \ldots \ldots \ldots \ldots \ldots \ldots . . \ldots \ldots \ldots 7$

Study Area and Methods ................ 9

Results ......................... 13

Nest fates ...................... 13

Mobbing behavior .................. 14

Female response .................. 15

Nost initiation datos .............. 15

Intra-specific nest parasitiem ....... 15

Discussion ..................... 17

Nest protection ................... 17

Early warning system ............... 20

Colonial nesting ................. 21

Abendonmont ..................... 22

Intra-specific nest parasitisn ....... 23

Conclusion $\ldots \ldots \ldots \ldots \ldots \ldots \ldots \ldots \ldots . . \ldots . . . . .25$

Litorature Cited ................... 27

Table ........................... 32

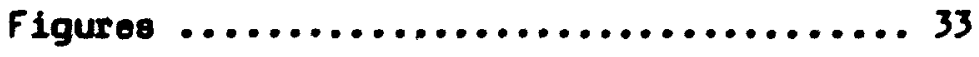

Appendix $\ldots \ldots \ldots \ldots \ldots \ldots \ldots \ldots \ldots \ldots \ldots . \ldots . \ldots . \ldots$ 


\section{LIST OF TABLES}

Page

Toble 1. Number of times an incubating fomale hed

already left the neet or fluched duing visits of tern colony, gull colony and solitary neats of Red -breasted Mergansers.

Table 2. Neat Pate percentages for the 3 study 36 sites if 31 neots abandoned following the marking of hens just prior to hatching are inclúded (I) and excluded (E). 
LIST Of FIGLRES

Figure 1. Nap of study iron.

$-33$

Figure 2. Percentage of preyed upon, successful and abandoned nests for tern colony, gull colony and solitary nests.

Figure 3. Percentage of total Tern Island nests 35 - initiated and subsequently successful during the nesting season.

'c

C

J

ai 


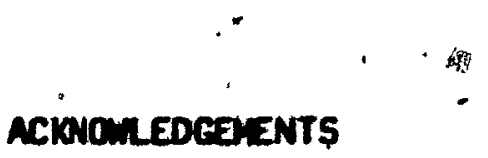

:

I scknow Ifodge the assistance, of Harry Beach and Mike Savoie of Kouchibouguec Niational Park for providing helpful suggestions about the Park Harry Beach also provided the number of tern nests found on Tern Island in July 1984. Dave Shutler and my wife Vicki provided field assistance. I thenk 'Parks Canada, Atlantic Region for allowing the study to be conducted in Kouchibouguac and Dr. Roger Bider for allowing me to wee his outboard motor. Eric Thompson of Macdonald College showed me how to calculate surface area from aerial photographs. Louise David trenslatiod the English abstract into Fronch. My parents Hume and Elinor doeerve special thanks, without them this study would never have taken place. My wifo Vicki provided comments on an earlier draft of this theais and emotional support throughout the study: Financial support for this study was made posaible through a Natural Sciencess and Engineering Rosenrch Council grent (E A-9700) to Rodger Titman. 
REGULATIONS ON THESIS PRESENTATION

The following 18 included in agcordance with the regulations of the McGill University Faculty of Graduate Studies:

"The candidate has the option, subject to the approval of the Department, of including as part of the thesis the text of an original paper, or papers, sultable for submission to learned journals for publication. In this case the thesis must still conform to all other requirements explained in Guidelines Concerning Thesis Preparation. Additional material (experimental and design data as well as descriptions of equipment) must be provided in sufficient detal to allow a clear and precise judgement to be made of the importance and * originality of the research reported. Abstract, full introduction and conclusion must be included, and where more than one manuscript appears, connecting texts and common abstracts, introduction and conclusions are required. A mere collection of manuscripts is not acceptable; nor can reprints of published papers be accepted.

While the inclusion of manuscripts co-authored by the Candidate and others is not prohibited by MCGill, the Candidate is warned to make an explicit statement on who contributed to such work and to what extent, and Supervisors and others will have to bear witness to the accuracy of such claims before the Oral Committee. It should be noted that the task of the External Examiner is made much more difficult in such ceses, and it is in the Candidate's interest to make authorship responsibilities perfectly cleer." 
PREFACE

The objective of this thesis was to test a priori hypotheses concerning some possible anti-predator strategles used by breeding Redbreasted Mergansers. Hypotheses tested were that Red-breasted Mergansers nested 1) in essociation with Common Terns 2) in association with Herring and Creater Black-backed Gul ls and 3) colonially as anti-predator strategies. I was unable to test an hypothesis that creching behavior in Red-breasted Mergansers serves an ant1-predator function. Broods were very hard to fol low over any length of time due to their great mobility and characteristics of the study area.

An original contribution of this thesis is that the anatid-larid nesting association was investigated in detall for an anatidspecies nesting with two separate larid species and alone.

A brief literature réview 18 included to provide additional background information on the hypotheses in accordance with the Guidelines Concerning Thesis Preparation. The information in the literature review is intended to compliment that already present in the introduction and discussion of the thesis although there is some overlap of information.

Rodger Titman contributed information on the nesting conditions of Red-breasted Merganers at Kouchibouguac National Park as well as suggestions about the study and editorial comments on earlier drafts of this manuscript. I formulated the hypotheses, designed the methodology to test them, col lected, analyzed and wrote up the data.

This thesis is being submitted in the form of a manuscript intended for publication in the Auk. My thesis aupervisor, Rodger Titman, will be 
a co-author of this manuscript.

(

t 


\section{LITERATLRE REVIEM}

European observers (Koskimies 1957, Hilden 1964; Newton and Campell 1975) heve reported a strong social attraction between some noating anatide and 1 arids. In central Scotland, Newton and Campboll (1975) found that Tufted Ducks (Aythye fuliqule) nested at much greater denaities in a Black-hasdod Gull (Larus rldibundus) colony than outaide 1t. The ettraction of Iufted Ducks to nest in larid colonies has been noted elsowhere (Durango 1954, Hilden 1964). In North America, a high incidence of nost association betwoen Arctic Terns (Sterna paradiseea) and 01 dequaws (Clangula hyenalis) was found at Churchill, Manitoba (Evans 1970). Vermeer (1968) provides ovidence that nesting Pintail (Anes ecuta) and Lesser Scaup (Aythye effinis) strongly associate with Comon Terns (Sterna hirundo). Among 6 small islands in central Alborta, neating densities of 11 duck species'were significantly higher on those islands inhabited by Comion Terns compared to those 18 lands without the terne (Vermeer 1970).

One reason for the obeerved nesting associations between waterfowl and larid species could be that waterfowl neats are provided protection from predators through the mobbing behevior of the Larids (Evans 1970, Long 1970). The anatid-larid nesting aseociation is poorly understood. When ducks nest in essociation with such larid species as Arctic Torns, Cammon Terns and Black-hoeded Gul lo, reproductive success cen incresee due to the protection provided the duck nests by the larids (Long 1970, Bengtson 1972, Newton and Campbel1 1975). Hetching success of Tufted Ducks, Mal lards (Anas platyrhynchos), Gadwal 1s (‥ etrepera), Wigeon (A. anericene) and Shoveler (A. clypeate) combined was higher in areas 
with Black-headed Gulla compared to areas without them (Newton and Campbel 1 1975). Long (1970) suggests that nest success of water fowl was promoted by the presence of Common Terns. When ducks nest in association with one of the larid species which are serious predators upon eggs and/or young, such as California (Larus californicus), Greater Blackbacked (ㄴ. marinus) and Herring. (느. argentatus) Gulls, reproductive 8uccess can be reduced (Odin 1957, Choate 1967, Vermeer 1968, Dwernychuk and Boag 1972, Bourget 1973, Munro and Bedard 1977). On islands in Penobscot Bay Maine, Bouget (1973) found greater than two thirds of the Common Eider (Somateria mollissima) eggs and young lost to predation were attributed to Greater Black-backed and Herring Gullo nesting with the eiders. Vermeer (1968) and Dwernychuk and Boag (1972) found that ducks had high hatching success when nesting in association with California and Ring-billed Gulls (L. delawarensis) but fledging success declined to zero due to predation by the gulls.

Beyond the benefit of two or more species nesting together, colonial nesting has certain anti-predator benefits of its own. In colonially nesting species, reproductive synchrony could be incresed through social stimulation. Eggs and young would thus be produced over a shorter period of time. This predator swamping effect may reduce total prodation as was first suggested by Darling (1938) and supported by Patterson (1965) working on the Black-headed Gul1. Colonial nesting may reduce the risk for an individual nest hidden in the colony (Hamilton 1971). Assuming that Hamilton's selfish herd theory applies, peripheral nests in colonies should be preyed upon in greater proportion than more centrally located nests as was found for nesting colonies of black- 
hoaded Gulls (Patter 8on 1965, Sandwich Terne-(Sterna sandvicensis, Fuchs 1977, Veen 1977) and Bank Swallows (Riparia riparia, Hoogland and Shormen 1976).

\section{LITERATURE CITED}

Bengteon, S.-A.1972. Reproduction and fluctuations in the size of duck populations at Lake Myvatn, Iceland. Oikos 23:35-58.

Bourget, A.A.1973. Relation of eiders and gulls nesting in mixed coloniea in Penobscot Bay, Maine. Auk 90:809-820.

Choste, J.S.1967. Factors affecting auccess of oiders in Penobscot Bay, Maine. J. Wildl. Manage. 31:769-777.

Darling, F.F.1938. Bird flocks and the breeding cycle. Cambridge Univereity Press, London.

Durango, S.1954. The Tufted Duck as a breeder in colonies of gulls and terns. (English sumary). Ornis Fenn. 31:1-18.

Dwornychuk, L.W., and D.A. Boag. 1972. Ducks nesting in association with gulls - an ecological trap? Can J. Zool. 50:559-563.

Evans, R.M.1970. Oldequawe nesting in sesociation with Arctic Terns at Churchill, Menitobe. Wilson Bull. 82:383-390.

Fucha, E.1977. Predation and anti-predator behavior in mixed colony of torns Sterne ap. and Biack-hoaded Gulls Larus ridibundus with special reforence to the Sandwich Tern Storne andviceneis. Ornis Scend. 8:17-32.

Hilden, 0.1964. Ecology of duck populations in the island group of Valessearet, Gulf of Bothnie. Ann. Zool. Forn. 1:153-277. Hoogland, J.L., and P.L. Shorman.1976. Advantages and disedvantages of Bank Swllow (Riparie riparia) coloniality. Ecol. Monogr. 46833-58. 
Koskimies, J.1957. Terns and gulls as features of habitat recognition for birds nesting in their colonies. Ornis Fenn. 34:1-6.

Long, R.J.1970. A study of nest-site selection by island-nesting Anatids in central Alberta. Unpub. M. Sc. thesis. University of Alberta, Edmonton. 123p.

Munro, J., and J. Bedard.1977. Gull predation and creching behaviour in the Common Eider. J. Anim. Ecol. 46:799-810.

Newton, I., and C.R.G. Campbel 1. 1975. Breeding of ducks at Loch Leven, Kinros8. Wildfow $126: 83-103$.

Odin, C.R.1957. California gull predation on waterfowl. Auk 74:185-202.

Patterson, I.J.1965. Timing and spacing of broods in the Black-headed Gull Larus ridibundus. Ibis 107:433-459.

Veen, J.1977. Functional and causal sepects of nest distribution in colonies of the Sandwich Tern (Sterna sandvicensis Lath.) Behaviour, Suppl. 20:1-93.

Vermeer, K.1968. Ecological aspects of ducks nesting in high densities anong Larids. Wilson Bull. 80:78-83.

----1970 . Some aspects of the nesting of ducks on islands in Lake Nowell, Alberta. J. Wildl. Manage. 34:126-129. 


\section{INTRODLCT ION}

Two or more bird species may nest together due to similar habitat preferences, food information sharing or predator avoidance (Erwin 1979). Several water fowl species nest in association with larids in Europe (Kaskimies 1957, Hilden 1964, Newton and Campbell 1975) and North America (Vermeer 1968,1970, Evans 1970, Long 1970, Dwernychuk and Boag 1972). Hilden (1964) found a positive correlation between the occurrence of neeting Red-breasted Mergensers (Merqus serrator) and the density of nesting larids.

Nests of one bird species may be provided protection when they are associated with those of a more aggressive protector species which actively defends its own nest ( Clark and Robertson 1979, Wiklund 1979, Gotmark and Anderson 1980, Slagsvold 1980, Dyrcz et al. 1981, Ericksson and Gotmark 1982). For example, waterfowl nests may be provided protection when they are associated with nests of aggressive larid species (Koskimies 1957, Evans 1970). Incubating females could also use the warning calls of the larids as an early warning to cover their nests and leave before the arrival of a predator. This has been reported for grebes nesting with larids (Nuechterlein 1981, Burger 1984).

The protective benefit of the anatid-larid nesting assciation has been documented in anecdotal fashion (Vermeer 1968, Evans 1970, Dwernychuk and Boag 1972) and a few authors have provided quantitative enalysis (01880n 1951 cited by Bourget 1973, Bengston 1972, Newton and Cempbel 1 1975).

Costs associated with mixed specios nesting aseoclations may cancel (Kruuk 1964) or outweigh the protective benefits (Vormeer 1968, 
Dwernychuk and Boag 1972). Kruuk (1964) reported that copts are invol ved when the protector species itsel if is a predator upon egge. From their 'otudies, Vermeer (1968) and Dwernychuk and Boag (1972) believed that costs rosulting from duckling mortality by gulls nesting with ducks exceeded the benefits of nest protection.

In colonially nesting species, incresed reproductive synchrony could produce egge and young over a shorter period of timo. A "predator swamping" effect would result and may reduce overall predation (Darling 1938). Colonial nesting may also reduce the risk for an individusl nest hidden in the colony (Hamilton 1971).

Hypotheses formulated were that Red-breasted Mergansers neated 1) in association with Common Terns (Sterne hirundo), 2) in association with Herring (Larus argentatus) and Greater Black-backed (L․ marinus) Gulls and 3) colonially as anti-predator atrategies. Predictions arising from the first two hypotheses were that a greater proportion of nests preyed upon would be outside the larid colonies and that laride would actively mob and exclude potential predatore from their colonies. In relation to the third hypothesis, I predicted that clumped nests would be initiated in greater synchrony than more dispersed nests and that peripheral nests of colonially nesting mergansers should have the highest predation rate. 
STUDY AREA AND METHODS

The study was conducted in Kouchibouguac National Park, on the east coest of Now Brunswlck, Caneda. Red-breasted Mergansers nested throughout a colony of 12,000 Common Tern peirs on Tern Island $\left(46^{\circ} 47^{\prime}\right.$ $N, 64^{\circ} 52^{\prime} W$ ), on the periphery of a Herring and Greater 81ack-backed Gull colony of approximately 130 and 5 pairs, respectively, and oolitarily away frow larid colonies on Dune Island $\left(46^{\circ} 45^{\prime} N, 64^{\circ}\right.$ 47'w) (Fig. 1). Nosts in the torn colony, gull colony and solitary sitos were compared to determine the offect that larids had on nesting. Comparisons were made between the densely concentrated nests in the tern colony ( 11.6 nest8/ha), with the more disperged nests in the gull colony, and solitary nests on Dune Island (0.35 nests/ha) to determine the effect of clumped versus dispersed nesting on nesting success.

Tern and Dune Islands are barrier islands composed of sand and stabilized by Marran Grase (Anmophile breviliqulata, McCann et al. 1973, Greenwood and Davideon-Arnott 1977). Tern Is land consisted of 3 aress separated at high tide by water. Merganser nests were quite often located in Marram Grass on elevated areas. Potential nest predators on the study area included Crows (Corvus brachyrhynchos), Ravens (Corvus corax), and Herring and Greater Black-backed Gulls.

Nest searching and monitoring was conduated from 5 June to 17 Auguet, 1984. Each area was visited every 7-9 days between 0900 and 1600 hours. Nest visite did not take place on rainy days and were done at the same time of the day in each area. Nesta were located while walking by looking in the gras8 80 that all parta of the ground were covered 
oystematically. When a nost was located it was marked with a green lathe placed 4m north of the nest bowl. The lathes were usually shorter than the surrounding vegatation in order to minimize the attraction of avian predetors (Picozzi 1975). The approximate position of the nest was recorded on a 1:2,000 scale eerial photograph. Besides noting the number of egge and whether egge were warm or cold, a plastic field candler (Young in prep.) modified from Sobkowiak and Bird (1984) was used to determine the stage of embryo development of 3-7 eggs from each nest. More egge were candled from a nest where developwent stages varied. The above data were collected when the nest was first found and on subsequent visitg every 7-9 days until the nest either hatched or was considered unsuccessful. All egge remaining in a nest thet hatched or failed were candled. Unknown dates of clutch initiation were determined by back dating. Embryo mortality in the egg was determined by candling 3-7 egge every visit over the life of the nest. A "new egg" was any egg added to the clutch when the other egge were at least 6 days developed in order to insure incubation had begun. An "unhatched but developed egg" was alive but not developed enough to hatch when the hen and brood left the nest.

In order to observe if terns and gul 18 were mobbing potential avian predators, 26 and 4 total hours of observation were done on the Tern and Dune Islands, respectively, from 6 June to 17 July from 0800 to 2130 . Observation periods varied from $11 / 2$ to 3 hours. A 3 meter high observation tower was constructed on 5 June on Tern Island while an elevated hill was used on Dune Island. A 20-45 power zoom telescope and 8 power binoculars facilitated obeervation which were recorded on tape. 
Reproductive synchrony of Tern Island and Dune Island nests were compared by examining the skewness, variance and kurtosis of the distributions of nest initiation dates for the 2 islands. The Chi-square test ( $2 \times 2$ contingency tablo) was used to compare the response of incubating merganser fenales to the investigator's presence for the tern colony, gul 1 colony and solitary neste (Daniel 1978). The Chi-square test was also used to comparo the proportions of different egg fates from Tern Island with those from Dune Island. The Fisher exact test was chosen to cospare the proportion of the different fates for nests from the tern colony, gul 1 colony and solitary sites (Daniel 1978) because of anal 1 expected frequencies in the $2 \times 2$ contingency table. A 0.05 level of aignificance was used for all tests.

To determine whether mergansers were using the alarm calls of terns and gullo as an early warning for their own escape (Nuechterlein 1981, Burger 1984) the frequency of flushing a fomale from her nest was compared to the numer of $t$ imes she had already gone and/or had already covered up her nest in response to observer visits to the nests. Only visits during incubation were used because females wore rarely at the nest during the laying period and only visits when egge were warm are included to provent including a fonsle as having gone in response t $\sigma^{\prime}$ larid calls when she had left the nest before the visit.

In an unsuccessful attempt to study creching behavior in Redbreasted Mergansers, fomel es were caught, during the 1 ast $1-4$ days of incubation with oither a hand hold not or an automatic nest trap (Woller 1957). Patagial tegs wore applied and enbled the recognition of femeles during the brood rearing period Infortunately it appoered that a total 
of 31 females abandoned their nests due to this process. These nests were thus considered successful in data analysis (see Appendix). This is a reasonable assumption since the nests had survived most of the nesting period and were within 1-4 days of hatching. No nest 10888 occurred during this time period for any of the other nests (although one nest was preyed upon 6 days before hatch). In fact, no other nest $1088 e 8$ occurred within 2 weoks of hatching. Abandonment would be unlikely during this period due to the female's strong attachment to the nest. Since the predation rate $(1 / 160)$ was very low an nests on the Tern Igland it is finlikely that a Tern Island nest would have been lost to predation at this time. There was a greater possiblity that loss aight hate occurred in the 4 Dune Island nests which were abandoned due to tagging because the predation rate $(5 / 22)$ was much higher there. Although this is ot 11 unlikely given that 4 nests were exposed to predation for only 3-4 days each out of a 41 day nesting period. 


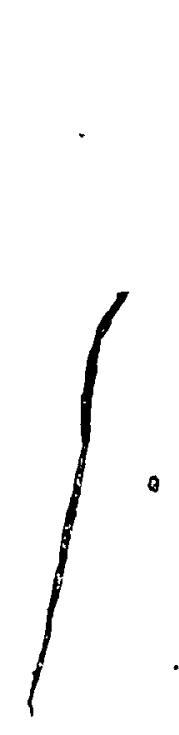

\section{RESULTS}

\section{Neat fatee}

The proportions of successful, abandoned and preyed upon nests in the tern colony, gull colony and solitary sites are shown in Figure 2. A significantly ( $p=0.00068)$ greater proportion of solitary nests was preyed upon than tern colony nests. No oignificant difference was found in the proportion of preyed upon nests from the gull colony compared with the tern colony $(p=0.115)$ or solitary nests $(p=0.249)$. A significantly $(p=0.00000011)$ greater proportion of nests was abandoned from tern colony nesta compared to the gull colony wile there were no significant differences in the proportion of abandoned nests in the tern colony and solitary nests $(p=0.106)$, gul 1 colony and solitary nests $(p=0.104)$ or the tern coliony compared with the gull colony and solitary nests combined ( $\left.p_{0}=0.059\right)$. No significant differences existed between the proportion of auccessful nesta from the gull colony compared to the tern colony $(p=0.34)$, solitary, and tern colony nests $(p=0.141)$ or solitary and gull colony nests $(p=0.156)$.

Abandonment accounted for 89.5\% (51/57) of total nest mortality while predation comprised only 10.5\% (6/57) of total nest mortality Thirty-eight and 13 nests were abandoned during laying and incubation, respectively. Nest los8, due mainly to abandonment was usually greatest during 4 day periods when the percent of nests initiated was highest (F Ig. 3).

A11 6 events of neat predation, moat likely by Crows and/or Ravens, occurred between 17 June and 29 June. Nests that were preyed upon had no eggs remaining in them and abput half of the nest bowl torn out. 
According to Rearden (1951) these are signs of crow predation. Crows often take the eggs away and eat them in another place (F. Gotmark, pers. comm.). Herring and Greater Black-backed Gulls, the other potential nest predators on the study area, tend to eat them on the spot (Tinbergen 1953, Bourget 1973), but this was not observed.

\section{Mobbing behavior}

During 26 hours of observation on the Tern Islands 7 events of tern flocks ie. greater than 40 ind 2 viduals, mobbing a single Crow were recorded. Terns were also seen mobbing a male Marsh Hawk (Circus cyaneus), an Osprey (Pandion haliaetus) and a Short-eared Owl (Asio flammeus). While nest searching, 2 more events of terns mobbing a single Crow were observed, 4 events of terns mobbing a Short-eared Owl and 1 mobbing event of a Barred Owl (Strix varia) were observed. Red-breasted Merganser females were also mobbed by tern flocks on 8 occasions while coming to or leaving a nest. On 3 occasions during nest initiation, females were forced of the vegetated area of the 191 and and onto the sand by mobbing terns. During $l$ of these events the female flew around the 13 land 3 times and landed back where she had taken off. Female mergansers were often mobbed by terns after being released from tagging.

During 4 hours of observation on the Dune, 2 events of a Greater Black-backed and 1 of a Herring Gull diving at a single Crow were observed. A Herring Gull was observed diving at and chasing a single Crow off the Dune. 


\section{Female response}

The number of times a female had already left the nest out of 491 visits during incubation depended on whether the nest was located in the tern colony, the gull colony or a solitary site (Table 1 ). The proportion of females that had already left the nest was significantly $\left(x^{2}=5.48,0.025<p<0.01\right)$ greater for nests within the tern colony than for solitary nests. Gull colony and solitary nest $\left(X^{2}=1.91, p>0.10\right)$ and tern colony and gull colony comparisons $\left(x^{2}=1.04, p>0.10\right)$ were not significantly different.

Nest initiation dates

Comparison of the distribution of nest initiation dates from Tern Island with Dune Island revealed that the former nests were not initiated in greater synchrony than the latter nests. The var 1 ance of Tern Is land nesta initiation dates (var.=163) was greater than Dune Island initiation dates (var.=90). The distribution of Dune Island initiation dates was slighlty more peaked (kurtosis $=2.36$ ) than the Tern Island distribution (kurtosis=1.93), al though both were relatively flat. Mean date of nest initiation was 10-11 June for Tern Island and 7-8 June for Dune Island.

Intra-specific nest parasitism

It was difficult to determine the extent of nest parasitism and the degree to which it affected nesting and hatching success. Nest parasit $18 \mathrm{~m}$ was more frequent in the densely concentrated Tern Island nests than in the more dispersed Dune Island nests. Tern Island nests had an average clutch size of 11.4 for 125 incubated nests, 37 of which had greater than 12 egg8. A total of 34 new egga were introduced into 
nests during incubation and there were 8 instances of a laying rate greater than 1 egg per day. The Dune Island nests had an average clutch size of 8.1 for 19 incubated clutches with none having greater than 12 eggs, no nests receiving new eggs and no instances of a laying rate more than 1 egg per day.

The effect of parasitism during the laying period was especially. hard to determine. One nest with a laying rate of greater than 1 egg per day was abandoned prior to incubation, likely due to parasitic intrusions. Parasitism may also have caused some desertions during incubation. Of the 12 Tern Is 1 and nests deserted during incubstion, 3 had no change in egg numbers but 9 had a total of 11 new eggs added and 29 eggs disappeared. In 3 of the nests recelving new eggs, 1 or more new eggs were found in the abandoned nests.

Incubated Tern Island clutches had a significantly $\left(x^{2}=5.75,0.025<p<0.01\right)$ greater proportion of eggs that died during embryo development $(84 / 1419,5.9 \%)$ than did the Dune Island clutches $(2 / 154,1.3 \%)$. The number of incubated Tern Island clutches with 14 or more egge with at least 1 egg mortality was significantly $\left(x^{2}=7.79,0.01<p<0.005\right)$ greater than clutches having 1 ess than 14 eggs. The hatching success of Tern Island nests $(729 / 911$, 80\%) was not lower than that of Dune Island nests $(66 / 84,76 \%)$. Unhatched but developed eggs made up the greatest proportion of egge that failed to hatch on Tern Is land (13\%) and Dune Island (15\%). 
DISCUSSION

Nest protection

The island nesting habit of waterfowl provides nest protection from mammalian predators (Hammond and Mann 1956, Duebbert 1966). Anatids nesting in association with larids on islands may be provided additional protection from avian predators by the mobbing behavior of the larids (Evans 1970). Koskimies (1957) suggested how such a nesting association could evolve. Waterfowl young imprint on the larids and the young from successful nests in larid colonies return to the breeding area using the larids as a cue for recognition of nesting habitat.

Few studies have provided quantitative evidence of the protective benefit. Ols8on (1951, cited by Bourget 1973) reported that Common Eiders (Somateria mollissima) nesting on lslands with Herring and Greater Black-backed Gulls had a lower percentage of nests preyed upon by Hooded Crows (Corvus corone cornix) than those nesting on is lands without gulls. Bengtson (1972) found that hatching success of Greater Scaup (Aythya marila) and Tufted Duck ( $\underline{A}$. fuliqula) nesta was higher in Black-headed Gull (Larus ridibundus) and Arctic Tern (Sterna paradisaea) colonies then in nests not as8ociated with the larids. Finally, Newton and Campbell (1975) recorded that nesting Tufted Ducks had higher hatching success and densities within than outside a Black-headed Gull colony.

In this atudy, the highest proportion of nesta preyed upon were solitary nests, next lowest were nests in the gull colony and then nests in the tern colony, indicating that merganser nests were better protected from avian predators when located in tern and gull colonies. 
Observatiens of terns and gullo mobbing and effectively repelling potential nest predators further showed that terns and gul 18 do act indirectly as protectore for mergenser nests in their colonies. The aggressive, densely concentrated terns appear to have provided better protection for merganser nests in their colony than the more widely spaced nesting gulls. Terns had an effective communal mobbing system, often mobbing avian predators in great numbers and chasing the predator quite a distance from the colony. Gull defensive efforts were by solitary individuals, most often confined to the individual's territory. Mergansers nested throughout the tern colony but only on the periphery of the gull colony where fewer gulls were available to repel predators. Herring and Greater Black-backed Gulls are known to prey heavily on waterfowl nests in some areas (Choate 1967, Bourget 1973). The gulls were not serious predators on merganser nests but kept out those that were. Tern and gull nests may act as a buffer for merganser nests during avian predation. The presence of many exposed tern and gull eggs could be favored by avian predators over the well concealed merganser eggs, especially when the predator's search time is limited by mobbing harassment from terns and gulls.

The proportion of successful nests was slightly higher in the gull colony than in the tern colony but the difference was not significant. Besed on nest densities, Tern Island provided the optimal nesting habitat (Bengtson 1972) and should have produced the greatest proportion of offspring. The gull colony nests were at much lower density. Nesting success in the gull colony did not account for duckling mortality due to predation by the gulls themselves. Vermeer (1968) and Dwernychuk and 
Boeg (1972) presented ovidence for a seemingly paradoxical situation of ducks nesting with gulls (Larus californicus and ㄴ. delawarensis) where the costs of duckling mortality exceeded the benefits of nest protection. Dwernychuk and Boag (1972) suggested thet this nesting association began when ducks initially nested with non-predatory Common Terns and then the 18 lands were colonized by predatory gulls. The association is maintained by the ennual recruitment of yearling and adult femeles to the traditional nesting 18 lande and these returning females do not discriminate between terns and gulls.

In this study, survival of ducklings from merganser nests in the gull colony relative to other nests was difficult to determine due to the large temporal and spatial separation of hatching nests, the great brood mobility and creching behavior. Any difference in mortality of ducklings from nests in the gull colony with other nests would be apparent only immediately after the ducklings left the islands. During this critical period, duckling survival from nests in the gull colony may have been reduced due to the close proximity of numerous breeding and non-breeding gullo and their young. Herring and Greater Black-backed Gulls are notorious predators of waterfowl young (Bourget 1973, Munro and Bedard 1977, Braun et al. 1980). This may also help to explain why nests in the gull colony were more successful than those in the tern colony and yet had a much lower density. After leaving the islands, broode moved quickly to the mainland shore, where all broods would be equally likely to encounter a predatory gull.

Based on nest densities, Red-bressted Mergansers seemed to prefer nesting with gullo to nesting solitarily. There was suitable unueed 
nesting habitat adjacent to the gull colony. The Red- breseted Merganser-gul 1 nesting association could be partially maintained by the return of fenales to the gull colony if benefits of nest protection were greater then the costs of duckling mortality. The nosting of mergansers with gulls cannot be accounted for solely by an anti-predator hypothesis because there was no significant difference in the number of nests preyed upon in the gull colony and eolitary nests.

Early warning system

A bird species may use the warning calla of a nesting associate to avaid predators. Grebes nesting in eseociation with larids respond to the warning calls of the laride by covering up their nest and leaving the nest before a predator arrives (Nuechterlein 1981, Burger 1984). Palmer (1976) stated that some Red-breasted Mergensers nesting in gulleries and terneries react to their warning calls. During some nest visits in this study, incubating female mergansers reacted to the warning calls of terns and gulls in response to the approaching investigator by leaving their nests early. However, even for nests in the tern colony where the response of females was greatest, just over half of hens not responding to the warning calla of the terns were flushed from a short distance. Hence, Red-breasted Mergansers and grebes do not seem to respond in the same way to the warning calls of laride, perhaps due to a difference in their predetors. Grebes faced with mammalian predators may need to escape beforehand to avoid predation. Red-breasted Mergansers, receiving most predation from egg predators such as Crows and Ravens may be better served by remaining to defend the nest against the predator. A female nesting solitarily apparently tried 
unsuccessfully to defend her nest; the remains of numerous merganser feathers and a corvid feather were found beside a nest that had been preyed upon. A Mallard (Anes pletyrhynchos) hen has been observed dofending her nest against Crowe (Hamond and Mann 1956). Milne (1974) suggeats that the Common Eider's hebit of remaining at the nest during the neating period may have developed in order to protect tbe egga from crows and gul 18. Similar behavior may function to protect egge of the Greeter Snow Goose (Chen hyperborea,Lemioux 1959).

\section{Colonial neating}

In colonial nesting associetions, breeding may be more synchronous due to intra-specific social atimulation resulting in production of egge and young over a shorter period of time. This predator swamping effect may reduce overall predation (Darling 1938). Examination of the nest initiation dates from the densely concentrated nesting mergensers on Tern Island with the more disparsed nesting mergansers on Dune Island showed that the colony nests were not initiated in any greater synchrony then the solitary nests. Nest 108808 were usually greatest during periods when the greatest percentage of nests was initiated (Fig. 4). Thus colonial nesting In this species probably does not function to produce a predator swamping offect and thus reduce overall predation. Colonial nesting may reduce the risk for a nest hidden in the colony (Hanilton 1971). If Hamilton's theory of the selfish herd applies, the predation rate should be highest on peripheral nests (Patterson 1965, Fuchs 1977, Veen 1977). This prediction could not be tested dive to the low predation rate on clumped Tern Island nests. Interestingly, both the 1 nest and the 1 incubating hen preyed upon wore located on the very 
periphery of the Tern Island. The nest distribution pattern on Tern Is land seemed to reflect the availability of suitable nesting cover rather than solection for nests to be hidden in the colony.

\section{Abandonment}

Abandonment was the greateat aingle cause of nest 1088 in this study. Mclaughlin and Grice (1952) documented that the rate of nest desertion in Wood Ducks (Aix sponse) was density dependent. Bengtson (1972) reported that hatching success in Barrows Goldeneye (Bucephala islandica) was significantly lower at high nesting densities due to a greater proportion of deserted nests. Duebbert et al. (1983) and Lokemoen et al. (1984) found an above average abandonment rate was the major cause of egg failure of densely nesting Mallards and Gadwalls (Anes strepera) on an island in North Dakota. They suggested that the high nesting densities of ducks max have increased intra-specific aggression and resulted in a higher rate of nest desertion. Lokemoen et al. 1984 believed that thick nesting cover was important to nesting hens because it screened hens on nests from harasement by other conspecific nesting hens. Red-breasted Mergansers preferred to nest in thick vegetation which may have acted as a screen for nesting mergensers, as well as providing shelter for femele mergansers being mobbed by terns. Alternatively, movoment in thickly vegotated areas was restricted to well fined pathways and tunnels where intra-specific conflicts may have been intensified, thus increasing the rate of abandonment. Nests in the tern colony had approximately 3 timos the proportion of abandoned neste compared with those in the gull colony and twice that in solitary nests. Nests in the tern colony were also by far the most densely, 
concentrated of the 3 nesting conditions, leading to increased frequency of intra-specific conflicts and thus the frequency of abandonment. $V$ igorous mobbing attacks by terns upon nesting female mergansers may have caused some abandorments. Nest parasitism may also have caused some abandonments, but this will be discussed shortly.

Although merganser nests on the Tern Island received the greatest amount of protection from avian predators, inter-and intra-specific competition on the island may have increased the number of females abandoning nesting attempts. The nesting success of an individual female in the tern colony may be higher than indicated by the overall rate of abandonment due to successful renesting attempts. The second phase of nest initiation (Fig. 4) may represent renesting attempts or be partly due to dolayed nesting to reduce intraspecific otrife as was suggested by McKinney (1965) for densely nesting Mallards.

Intre-specific nest perasitiom

The degree of intraspecific parasitism appears to be density dependent in waterfowl (Wellor 1959, Hilden 1964). Intra-specific parasitiam by the Red-breseted' Merganser is fairly common (see Hilden 1964). Parasitian was more frequent anong the densely concentrated Tern Island nests than in the more dispersed Dune Island nests. Weller (1959) pointed out that one response of the nesting host female to continuous parsitic intrusion is desertion and that this is most likely to occur early in the laying stage when the females' attachwent to the nest aite is weakest. Jenkins et al. (1975) found that nest $1088 e 8$ due to desertion in denaely nesting Sholducks (Tadorne tedorne) were high and attributed some of these desertions to intra-specific parseition. 
Pienkowski and Evans (1982) reported that at least one third of the densely nesting Shelduck clutches studied were the product of more than 1 female. They reported that desertion in these mulfiple clutches was significantly greater than in those laid by a single female. Detecting the effects of parasitism on nest abandonment is difficult. One nest with a laying rate of greater than 1 egg per day may have been abandoned during laying as a result of parasitism. Most of the Tern Island nests abandoned during incubation had new eggs introduced or eggs lost from the clutch. Some of these females very likely deserted in response to parasitic intrusions.

Nest parasitism can reduce hatching success through embryo mortality due to egge broken during normal nest movements on a large nest or inefficient incubation of a large clutch leading to chilling of some egge (Weller 1959). Embryo mortality was higher on Tern Island than thet on Dune Island and was more frequent in clutches containing greater then 14 egge. A higher incidence of embryo mortality on the Tern Island and in larger clutches wes probably the result of intra-specific nest parasitien. Hatching success of successful Tern Island clutches was not greatly affected by embryo mortality because it comprised a small percentage of unhatched egge. 
CONCLUSION

Red-breasted Mergansers derived a protective benefit by nesting in a Common Torn colony compared to nesting solitarily. Mergenser nests in a Herring and Greater Black-backed Gull colany were provided a level of protection between that provided by the tern colony and solitary nests. The merganser-gul 1 nesting association cannot be accounted for by an anti-predator hypothesis alone. Nests in the tern colony were more likely to be abandoned probably due to the increased interaction between mergansers and terns at high nesting densities. Nest parasitism was greater in the tern colony and very likely caused some nest desertions and reduced hatching success. Nesting aynchrony was not increased by clumped nesting in the tern colany and therefore probably does not function to produce a predator swamping effect and reduce overall predation. Clumped nesting seemed to reflect the availabilty of sultable nest sites in preferred nesting habitat of the tern colony rather than selection for nests to be hidden in the aggregation of mergenser nests. Nesta in the gull colony may have experienced a higher duckling mortality as a result of predation by the gulls themselves. The protective benefit of the mergenser-tern nesting association exceeded the observed costs. The protective benefit for merganser nests in a tern colony appears to account for the evolution and maintenance of the nesting association. Red-breasted Mergansers proforred to nest in the tern colony, as their nest density there very high. Bengtson (19970) stated that the highest densities are found in the optimal habitats. If this is true, Tern Island provided optimal nesting habitat for Redbreasted Mergansers while the gull colony and solitary nesting 
conditions on Dune Island are suboptimal.

0

$-$

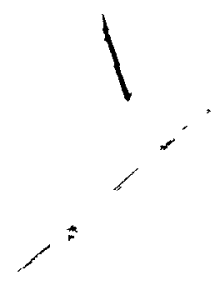

1

(

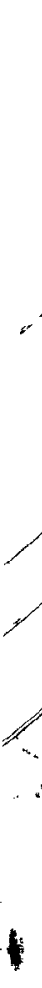

$\checkmark$

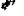

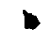

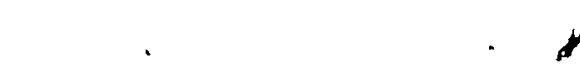




\section{LITERATURE CITED}

Bengtson, S.-A.1970. Location of nest-8ites of ducks in the Lake Myvatn area, north-east Iceland. 0ikos 21:218-229.

o -1972. Reproduction and fluctuations in the size of duck populations at Lake Myvatn, Iceland. 0ikos 23:35-58.

Bourget, A.A.1973. Relation of eiders arid gulls nesting in mixed colonies in Penobacot Bay, Maine. Auk 90:809-820.

Braun, B.M., P.A. Hienz and G. H. Hienz.1980. Herring gull predation on Red-breasted Merganser ducklings. Wilson Bull. 92:403.

Burger, J.1984. Grebes nesting in gull colonies: protective essociations and early warning function. Amer. Nat. 123:327-337.

Choate, J.S.1967. Factors influencing success of eiders in Penobscot Bay, Maine. J. Wildl. Manage. 31:769-777.

Clark, K.L., and R.J. Robertson.1979. Spatial and temporal multi-species nesting aggregations in birds as anti-parasite and anti-predator defences. Behav. Ecol. Sociobiol. '5:359-371.

Daniel, W.W.1978. Applied Nonparametric Statistics. Houghton Mifflin Company, Boston.

Darling,' F.f.1938. Bird flocks and. the breeding cycle. Cambridge University Press, London.

Duebbert, H.F.1966. Is land nesting of Gadwall in North Dakota. Wilson Bull. 78:12-25.

Duebbert, H.F., J.T. Lokemoen and D.E. Sharp.1983. Concentrated nesting of mallards and gadwal 18 on Miller Lake Is 1 and, North Dakota. J. Wildl. Manage. 47:729-740. 
Dwernychuk, L.W., and D.A. Boag.1972. Ducks nesting in association with gulls-- an ecological trap? Can. J. Zool. 50:559-563.

Dyrcz,A., J. Watkowsk 1 and J. Okulewicz.1981. Nesting of 'timid' waders in the vicinity of 'bold' ones as an anti-predator adaptation. Ib 15 $123: 542-545$.

Erıcksson, M.O.G., and F. Gotmark.1982. Habitat selectıon: Do passerines nest in association with Lapwings Vanellus vanel lus as defence against predators? Ornis Scand. 13:189-192.

Erwin, R.M.1979. Species interactions in a mixed colony of Common Terns (Sterna hirundo) and Black Skimmera (Rynchops niger). Anım. B Behav. $27: 1054-1062$.

Evans, R.M.1970. 01dsquaws nesting in association with arctic terns at Churchill, Manitoba. W1 lson Bull. 82:383-390.

Fuchs, E.1977. Predation and ant1-predator behavior in a mixed colony of terns Sterna $8 p$. and black-headed gulls Larus ridibundus with special reference to the sandwich tern Sterna sandvicensis. Ornis Scand. 8: 17-32.

Gotmark, F., and M. Anderson.1980. Breeding association between Common Gull Larus canus and Arctic Skua Sternacorarius parasiticus. Ornis Scand. $11: 121-124$.

Greenwood, B., and R. Davidson-Arnott.1977. An interpretive study of casatal processes, Kouchibouguac National Park, New Brunswick. Unpub. report submitted to Parks Caneda, Atlantic region. $398 \mathrm{p}$. Hamilton, W.D.1971. Geometry for the selfigh herd. J. theor. Biol. $31: 295-311$. 
Hammond, M.C., and G.E. Mann.1956. Waterfowl nesting islands. J. Wild. Manege. 20:345-352.

Hilden, 0.1964. Ecology of duck populations in the 181 and group of Valassagret, Gulf of Bothn1a. Ann. Zool. Fenn. 1:153-277.

Jenkins, D., M.G. Murray and P. Hall.1975. Structure and regulation of a Shelduck (Tadorna tadorna L.) population. J. Anim. Ecg1. 44:201231.

Koskimies, J.1957. Terne and gulls as features of habitat recognition for birds nesting in the1r colonies. Ornis Fenn. 34:1-6.

Kruuk, H.1964. Predatora and ant1-predator behaviour of the Black-headed Gul 1 (Larus ridibundus L.) Behaviour, Suppl. 11:1-129.

Lemieux, L.1959. The breeding biology of the Greater Snow Goose on Bylot Island, Northwest Territories. Can. Field Nat. 73:117-128.

Lokemoen, J.T., H.F. Duebbert and D.E. Sharp. 1984. Nest spacing, habitat selection, and behavior of waterfowl on Miller Lake Island, North Dakota. J. W1ldl: Manege. 48:309-321.

Long, R.L.1970. A study of nest-81te selection by 1 sland-nesting Anatids in central Alberta. Unpub. M. Sc.thesis, University of Alberta, Edmonton. $123 \mathrm{p}$.

McCam, S.B., E.A. Bryant and R.S. Seely.1973. Barrier 28land, shoreland and dune gurvey, Kouchibouguac National Park. Unpub. report subaitted to Parks Caneda, Atlantic Region. $156 \mathrm{p}$.

Mckinnoy, F.1965. Spacing and chasing in breeding ducks. Wildfowl 16:92106. 
McLaughlin, C.L., and D. Grice.1952. The effectiveness of large scale erection of wood duck boxes as a management procedure. Irans. N. Amer. W1ldl. Conf. 17:242-259.

Milne, H.1974. Breeding numbers and reproductive rate of Eiders at the Sands of Forvie National Nature Reserve, Scotland. Ib18 116:135152.

Munro, J., and J. Bedard.1977. Gull predation and creching behaviour in the Common E1der. J. An1m. Ecol. 46:799-810.

Newton, I., and C.R.G. Campbell. 1975. Breeding of ducks at Loch Leven, Kinrose. Wild fowl $26: 83-103$.

Nuechterle1n, G.L.1981. Information parasitism in mixed colonies of Western grebes and Forster's terns. Anim. Behav. 29:985-989.

01 sson,V.1951. The birds of the Kallaskar, Harvringe and Hartso archipelagoes, results of a bird census made in 1949. Var Fagelvarld 10:173-175.

Palmer, R.S.1976. Hendbook of North American Birds, vol. 3. Yale University Press, New Haven.

Patterson, I.J.1965. Timing and spacing of broods in the 81 ack-headed gull Larus ridibundus. Ibis 107:433-459.

Picozzi, N.1975. Crow predation on marked nests. J. Wildl. Manage. $39: 151-155$.

Pienkowski, M.W., and P.R. Evans.1982. Clutch parasitism and nesting interference between Shelducks at Aberlady Bay. Wildfowl 33:159163.

Rearden, J.D.1951. Identification of waterfowl nest predators. J. Wildl. Manage. 15:386-395. 
Slegsvold, T. 1980. Habitat selection in birds: on the presence of other bird species with special regard to Turdus pilaris. J. Anim. Ecol. $49: 523-536$.

Sobkowiak, S.T., and D.M. Bird. A portable candler for determing fertility and development of birds' eggs. J. Field Ornithol. . 55:257-258.

Tinbergen, N.1953. The Herring Gull's world. Coll1ns, London.

Veen, J.1977. Functional and causal aspects of nest distribution in colonies of the sandwich tern (Sterng s. sandvicensis Lath.) Behaviour Suppl. 20:1-93.

Vermeer, K.1968. Ecological sspects of ducks nesting in high densities among Larids. Wilson Bull. 80:78-83.

----1970 . Some aspects of the nesting of ducks in Lake Newe 1 1, Alberta. J. Wildl. Manege. $34: 126-129$.

Weller, M.W.1957. An automatic nest-trap for waterfowl. J. Wildl. Manage. 20:111-113.

----1959. Parasitic egg laying in the Redhead (Aythya americana) and other North American Anatidae. Ecol. Monogr . 29:333-365.

Wiklund, C.G.1979. Increased breeding success for Merlins Falco columbarius nesting among colonies of Fieldfares Turdus pilaris. Ibis $121: 109-111$. 
Table L. Number of times an incubating fomale had already loft the nest or flushed during visite of tern colony, gull colony and solitary nests of Red-breasted Mergeneers.

Tern Colony Cull Colony Solitary

fomale already

202

14

4

left nest

female fluehed

232

23

16

from neat

TOTAL

434

37

20 
Figure 1. Map of the study area in Kouchibouguac Netional Park, New Brunswick. 


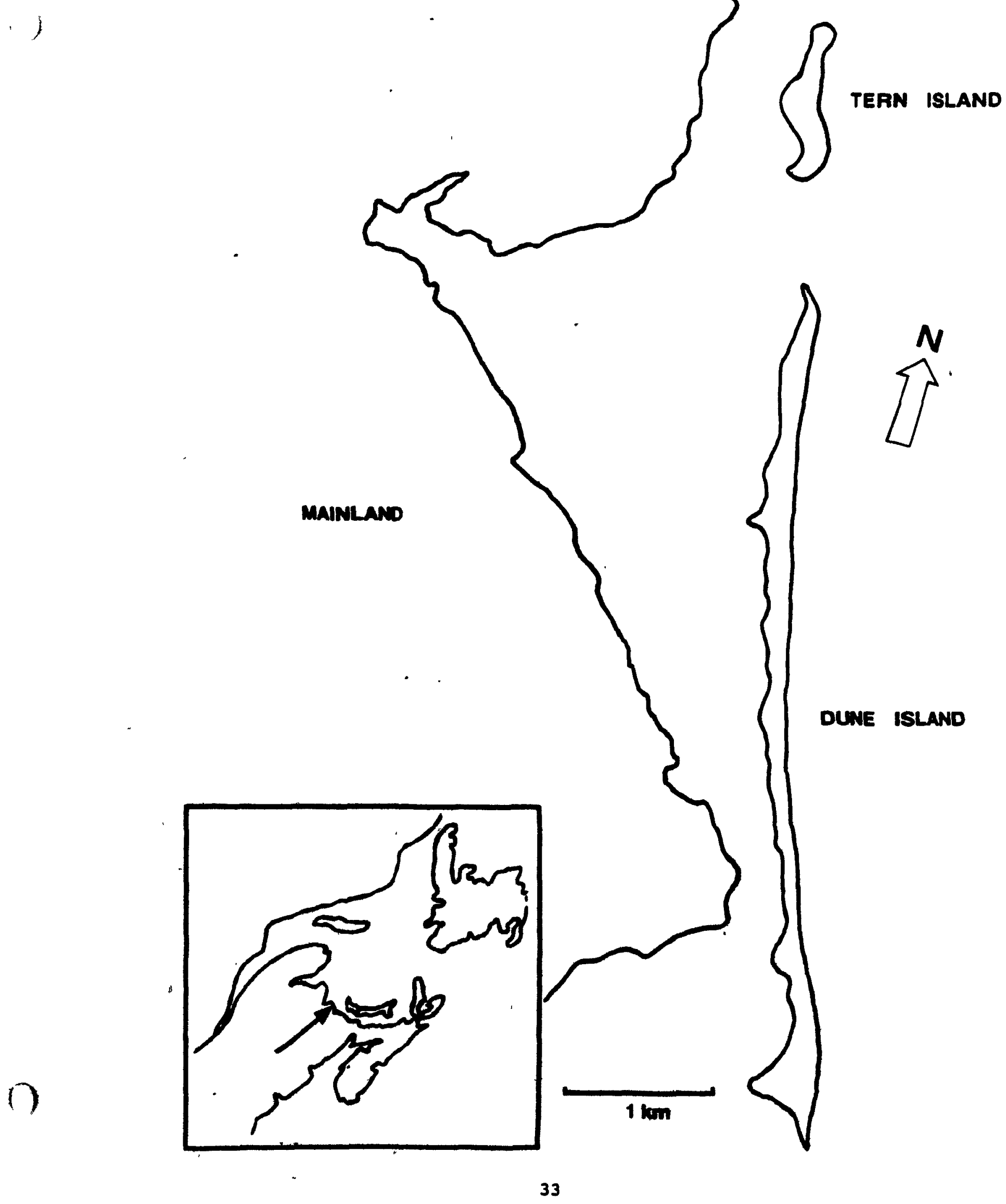



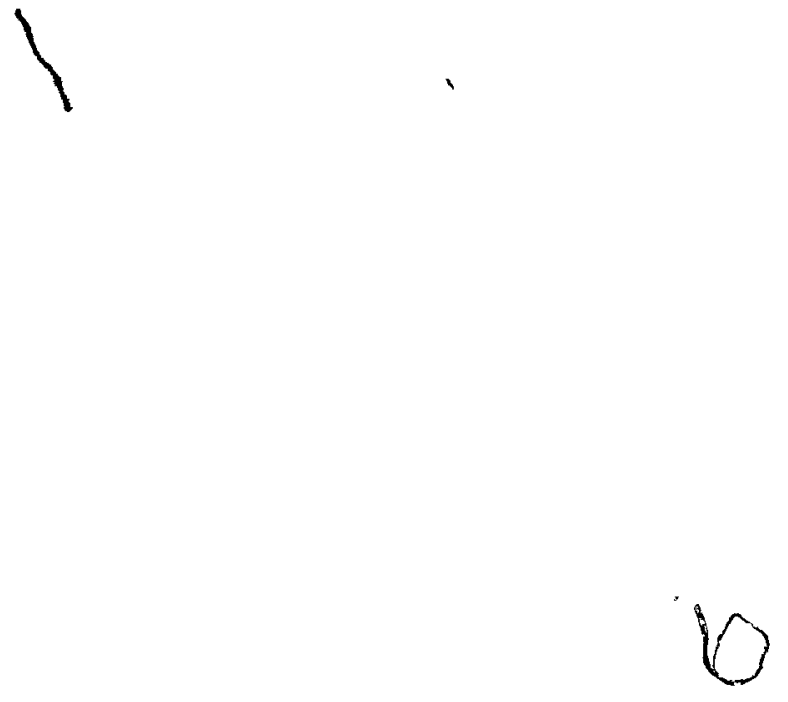

Figure 2. Percentage of preyed upon, successful and abandoned nests for tern colomy, gull colony and solitary nesta. 


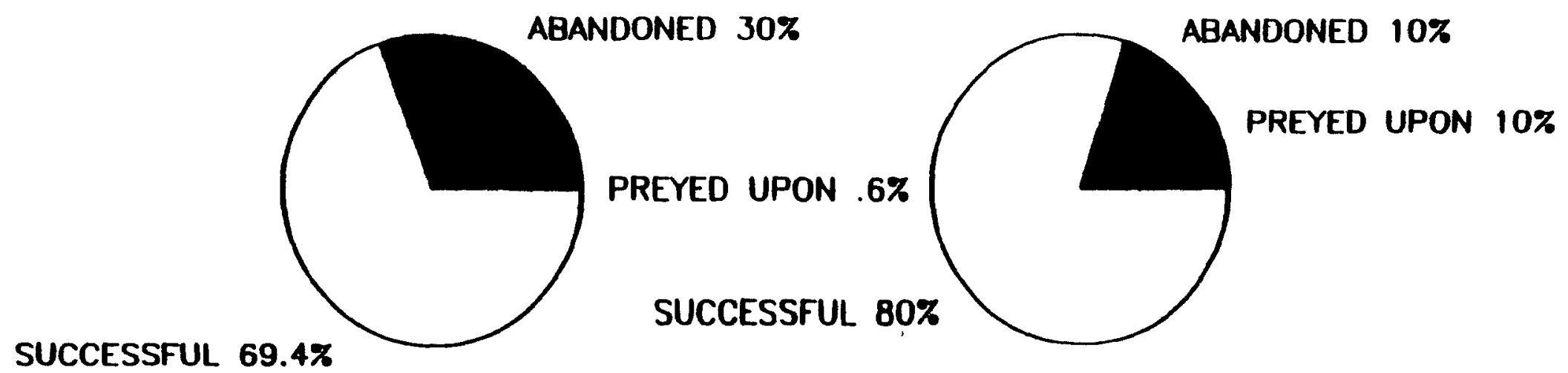

TERN COLONY $(n=160)$ GULL COLONY $(n=10)$

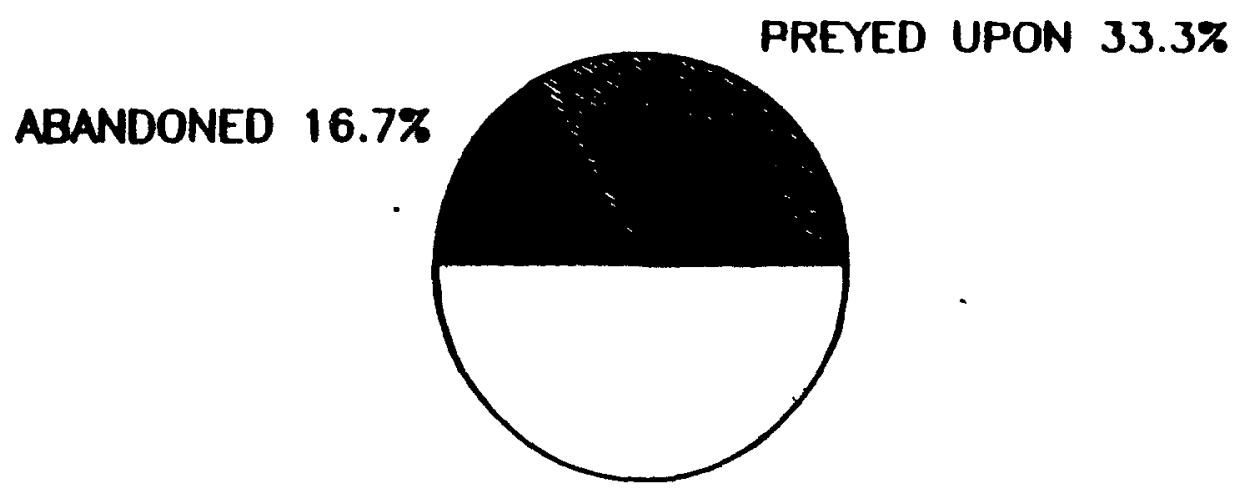

SUCCESSFUL $50 \%$

SOLITARY $(n=12)$ 
Figure 3. Percentage of total Tern Island neats initiated and subsequently successful during the nesting sesson. 


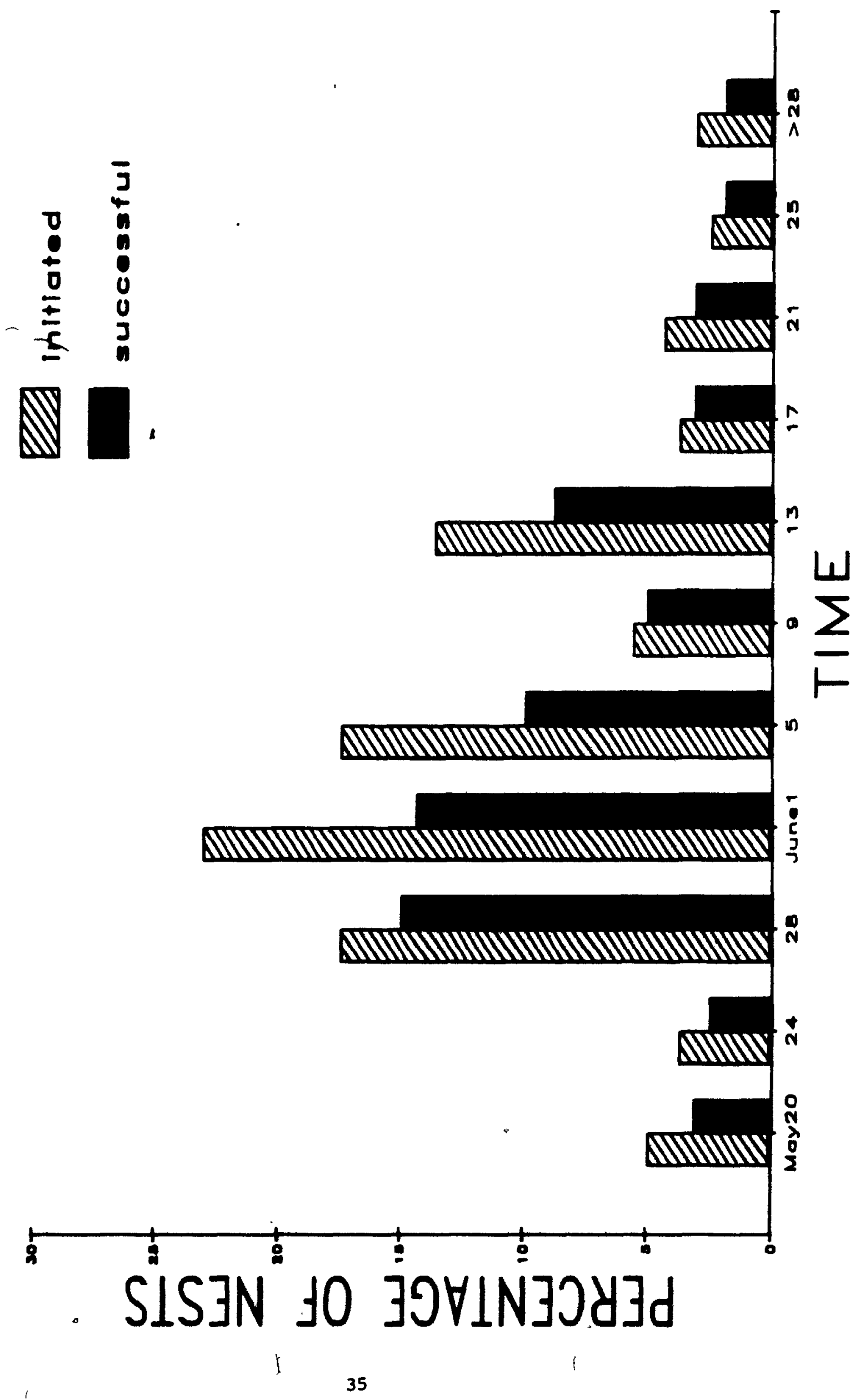




\section{APPENRIX}

If the 31 nests that were abandoned following the marking of hens are excluded from data analysis, the proportions of nest fates from the 3 sites would be biased. These nests were very likely to have been successful because they were abandoned 1-2 days prior to hatching. The exclusion of the 31 nests would result in unrealistically low percentages of successful nests and unrealistically high percentants of preyed upon and abandoned nests from 3 sites. For comparison, the percentage of preyed upon, successful and abandoned nests from tern colony, gull colony and solitary sites are considered (Table 2), including and excluding the late abandoned nests.

Table,2. Nest fate percentages for the 3 study sites if the 31 nests abandoned following the marking of hens just prior to hatching are included (I) and excluded (E).

1

Tern colony

Gull colony

Solitary

I E

successful

$$
69.4
$$

63.0

I E

I E

proyed upon

$$
0.6
$$

0.8

$80.0 \quad 75.0$

$50.0 \quad 40.0$

preyed upon

30.0

36.2

10.0

12.5

16.7

33.340 .0

abendoned

30.0

36.2

TOTALS

$100.0 \quad 100.0$

100.

100.0

$100.0 \quad 100.0$ 